\title{
Protective Effect of Quercetin on Histomorphometric Changes in Kidney of Retinoid Acid-Treated Rat Fetuses
}

\author{
Efecto Protector de la Quercetina sobre los Cambios Histomorfométricos \\ en el Riñón de Fetos de Rata Tratados con Ácido Retinoico
}

Mahmood Khaksary-Mahabady ${ }^{1}$; Reza Ranjbar ${ }^{1}$; Hossein Najafzadeh-Varzi²; Babak Mohammadian ${ }^{3} \&$ Nahid Gohari-Behbahani ${ }^{4}$

KHAKSARY-MAHABADY, M.; RANJBAR, R.; NAJAFZADEH-VARZI, H.; MOHAMMADIAN, B. \& GOHARI-BEHBAHANI, N. Protective effect of quercetin on histomorphometric changes in kidney of retinoid acid-treated rat fetuses. Int. J. Morphol., 36(1):338-344, 2018.

SUMMARY: Retinoic acid, an active metabolite of vitamin A, plays essential signaling roles in mammalian embryogenesis. Prenatal rat fetuse exposure to retinoid induces some malformations in various organs, the most active and teratogenic metablolite is all-transretinoic acid (atRA). The teratogenic effects of some drugs can be prevented by the application of antioxidant drugs and stimulation of the maternal immune system. Also, quercetin, a naturally occurring flavonoid has excellent antioxidant properties. Therefore, the aim of this study was assess the protective effects of quercetin against atRA in fetuses of rat's kidney tissue. This study was performed on 40 pregnant rats that were divided into seven groups. Control group received normal saline and test groups received DMSO, quercetin (75 mg/kg), quercetin (200 mg/kg), atRA (25 mg/kg), atRA (25 mg/kg) plus quercetin (75 mg/kg) and atRA (25 mg/kg) plus quercetin (200 mg/kg), intraperitoneally at 8-10th days of gestation. Fetuses were collected at 20th day of gestation. Kidneys were collected and placed in $10 \%$ buffered formalin solution. Then, kidneys were sectioned by routine method and stained by H\&E and examined histologically. On histomorphomertrical examination, it was observed the priglomerular space and diameter of renal corpuscle in group which received only atRA were significantly $(\mathrm{p} \leq 0.05)$ greater than those received normal saline, dimethyl sulfoxide and quercetin, while these two indexes in group which received atRA plus quercetin significantly $(\mathrm{p} \leq 0.05)$ decreased by quercetin as dose dependent manner. Number of renal corpuscles were significantly $(\mathrm{p} \leq 0.05)$ decreased by atRA, but the quercetin could not affect the glomerular numbers. It is concluded that quercetin can protect fetuses against atRA damages and prevent their incidence probably via its antioxidant effect.

KEY WORDS: Retinoic acid; Quercetin; Histomorphometry; Fetus; Rat.

\section{INTRODUCTION}

Vitamin A (retinol) and its analogs (retinoids) are important regulators of cell proliferation, differentiation, immune function, and apoptosis. Retinoic acid (RA), which exists in both cis and trans isomeric forms, is the most biologically active metabolite of vitamin A and is also essential for normal development (Abu-Abed et al., 2002). All-transretinoic acid (atRA), is a signaling molecule indispensable for the formation of many organs, including eyes, heart, and kidneys) Duester, 2008). AtRA is an important physiological regulator of cellular differentiation, proliferation, apoptosis, reproduction and embryonic development in many species (Maden, 2006). Retinoic action is mediated by specific nuclear retinoic acid receptors and retinoid receptors belonging to the steroid/thyroid super-family of transcription factors. Inadequate levels of retinoids (excess or deficiency) may result in a set of defects denoted retinoic acid embryopathy which may provoke defects in the development of the neural crista (Kam et al., 2012). The kidneys are target organs for vitamin A action. Retinoic acid (RA), a vitamin A metabolite, is involved in embryonic kidney patterning through the control of receptor tyrosine kinase expression, which modulates ureteric bud branching morphogenesis. Vitamin A status of the mother profoundly affects kidney organogenesis of the newborn (Bhat \& Manolescu, 2006).

AtRA affects by serving as an activating ligand of nuclear atRA receptors (RAR a, $b$, and $g$ ) and peroxisome proliferator-activated receptors (PPAR b/d), which form heterodimers with retinoid X receptors (Mark et al., 2006). In kidney atRA receptors are cell specific in expression; these

${ }^{1}$ Department of Anatomy and Embryology, Faculty of Veterinary Medicine, Shahid Chamran University of Ahvaz, Ahvaz, Iran.

${ }^{2}$ Department of Pharmacology, Faculty of Veterinary Medicine, Shahid Chamran University of Ahvaz, Ahvaz, Iran.

${ }^{3}$ Department of Pathology, Faculty of Veterinary Medicine, Shahid Chamran University of Ahvaz, Ahvaz, Iran.

${ }^{4}$ Veterinary Anatomical Sciences, Faculty of Veterinary Medicine, Shahid Chamran University of Ahvaz, Ahvaz, Iran. 
are therefore, practically responsible for activation of both receptors by their respective agonists (Wagner, 2001).

The concentration of atRA during embryonic development is tightly controlled in a spatial and temporal manner, and in adult tissues, it is maintained within a very narrow range that is specific for each given tissue. If the control mechanisms fail and the concentration of atRA exceed or fall below the optimal range, tissues and cells undergo pathophysiological changes that in most severe cases can lead to disease (Mark et al.). Development of the kidney is reported to be the result of interactions between the metanephric and ureteric bud mesenchyme in the presence of retinoids (Vilar $e t$ al., 1996).

Embryopathy due to RA is being intensely investigated in view of the teratogenic potential of retinols and of the crucial role played by their receptors in embryo development. AtRA increases the production of reactive oxygen species and oxidative stress (Notario et al., 2003).

Quercetin (3,30,40,5,7-pentahydroxyflavone) is a flavonoid commonly found in frequently consumed foods, including apples, berries, onion, tea, nuts, seed and vegetables that represent an integral part of the human diet. Quercetin is one of the most abundant representing the 60-75\% of the average polyphenol ingestion (Goldberg et al., 1995). Quercetin has been reported to have biological, pharmacological, and medicinal activities that are believed to arise from its antioxidant properties (Perez-Vizcaino et al., 2009). Quercetin could prevent oxidant injury and cell death by several mechanisms, such as scavengening oxygen radicals, protecting against lipid peroxidation and chelating metal ions. Quercetin directly scavenges the superoxide anion and inhibits several superoxide-generating enzymes such as xanthine oxidase (XO) or the neutrophil membrane NADPH oxidase complex (Maciel et al., 2013).

As above was mentioned atRA increases oxidative stress and quercetin acts as antioxidant; in present study, the preventive effect of quercetin on histomorphometrical changes in kidney of fetuses of rat treated by atRA was evaluated.

\section{MATERIAL AND METHOD}

Animals. Male and female healthy rats of Wistar strain, 3-4 month old, weighing 200-220 g were purchased (Joundishapour laboratory animal center, Ahvaz, Iran) and housed individually (males) or at 10 per polycarbonate cage (female) for a 2 -week acclimation period. Rats were fed ad libitum by standard laboratory pellet (Pars khurakdam, Tehran, Iran.) and tap water.
A $12 \mathrm{~h}$ light: $12 \mathrm{~h}$ dark was mentioned. Room temperature was at $23 \pm 2{ }^{\circ} \mathrm{C}$ with a relative humidity of $45-55 \%$. This experimental study was done in animal model in department of basic sciences of faculty of veterinary medicine of Shahid Chamram University (Ahvaz-Iran). The animal care was provided under the supervision of a qualified veterinarian.

Females were mated overnight with males. Pregnancy was ascertained the next morning by presence of a vaginal plug, and this time was designated as gestational day (GD) 0 .

Drug administration. Pregnant rats $(\mathrm{n}=40)$ were randomly divided into seven groups and treated as follow:

Group 1: Control group: normal saline was administrated to pregnant rats for inducing similar condition (injection and handling) to other groups.

Group 2: atRA ( $25 \mathrm{mg} / \mathrm{kg})$ was intraperitoneally administrated at 810th days of gestation.

Group 3: Dimethylsulfoxide as atRA solvent was intraperitoneally administrated to pregnant rats for inducing similar condition (effect of solvent) to other groups.

Group 4: quercetin $(75 \mathrm{mg} / \mathrm{kg})$ was intraperitoneally administrated at 8-10th days of gestation.

Group 5: quercetin $(200 \mathrm{mg} / \mathrm{kg})$ was intraperitoneally administrated at 8-10th day of gestation.

Group 6: atRA (25 mg/kg) plus quercetin $(75 \mathrm{mg} / \mathrm{kg})$ was intraperitoneally administrated at 8-10th day of gestation.

Group 7: atRA $(25 \mathrm{mg} / \mathrm{kg})$ plus quercetin $(200 \mathrm{mg} / \mathrm{kg})$ was intraperitoneally administrated at 8-10th day of gestation.

Sampling and staining. The animals were sacrificed by euthanized and cervical dislocation at 20th day of gestation and a midline longitudinal incision was given from xiphisternum to pubic symphysis to expose the uterus; implantation sites in the uterine horns, number of intact fetuses and resorbed embryonic masses were counted. Fetuses were dissected using dissecting stereomicroscope and their kidneys were removed and fixed in $10 \%$ formalin for $72 \mathrm{~h}$ for histological preparation. The specimens were dehydrated through a graded series of alcohol, cleared in xylene and infiltrated with molten paraffin before preparing the paraffin blocks; $5 \mu \mathrm{m}$ thick sections were obtained, using rotatory microtome. The sections were stained with standard hematoxylin and eosin method before examining them under the light microscope (Fig. 1). Measurement of diameter periglomerular thickness and diameter of renal corpuscles was made after calibrating eyepiece graticule with stage micrometer at various magnifications using $\mathrm{x} 10$ and $\times 40$ objectives.

Statistical. Statistical significance between groups was determined using SPSS program and compared by one-way analysis of variance (ANOVA) and Post hoc LSD. The minimum level of significance was $p<0.05$. 


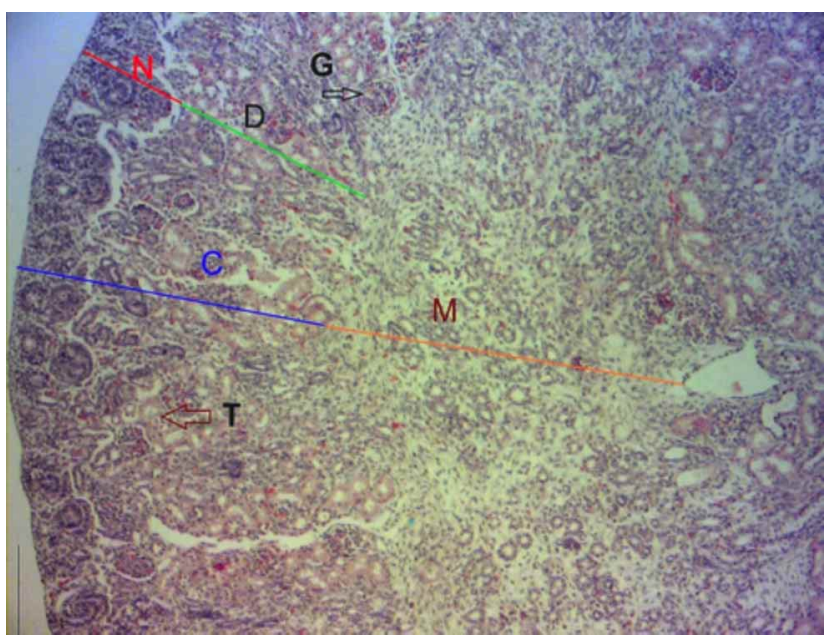

Fig. 1. Histological structure of sagittal section of fetal kidney of control showing cortex $(\mathrm{C})$, medulla $(\mathrm{M})$, nephrogenic $(\mathrm{N})$, deep cortex (D), Renal corpuscles (G) and cross sections of cortical ducts (T), (H \& E 10X).
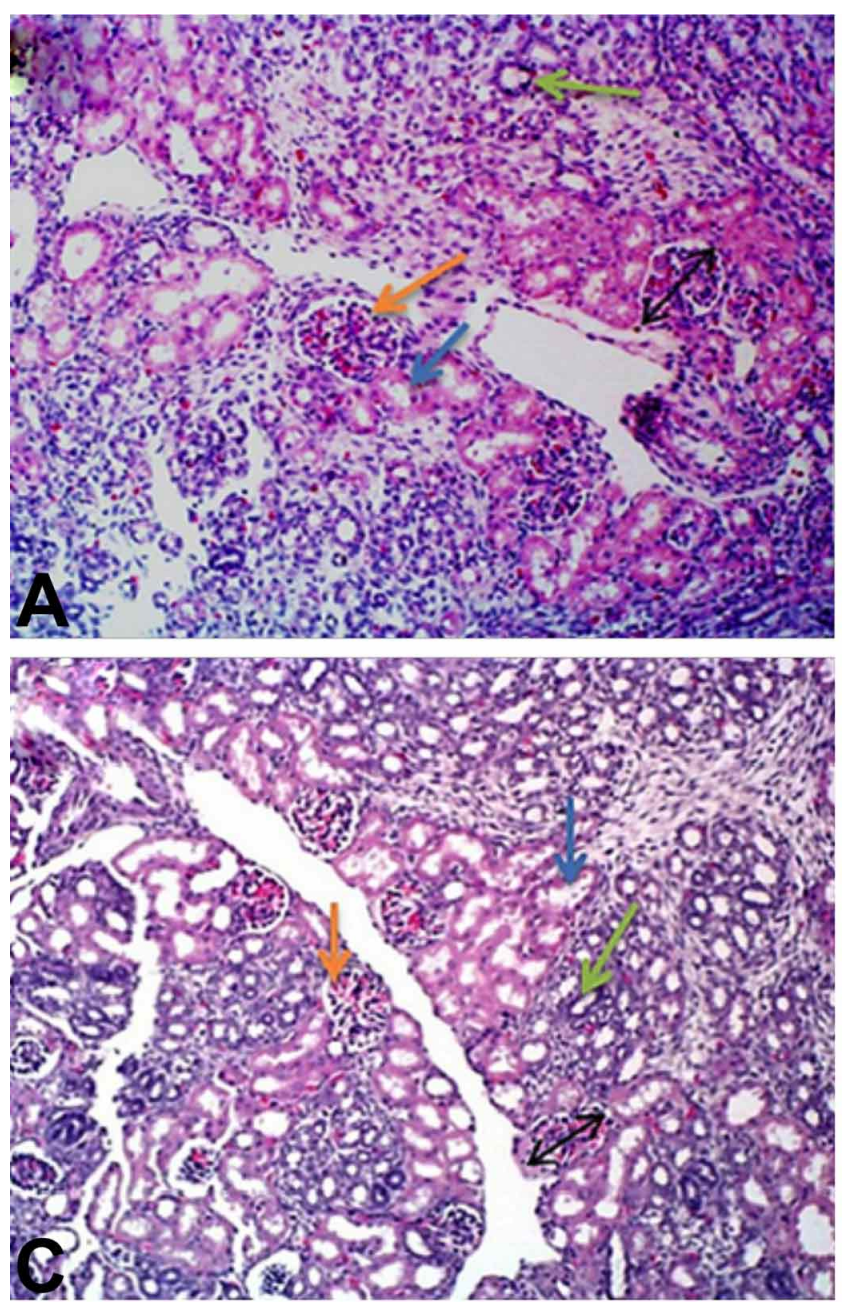

Fig. 2. Histological structure of sagittal section of fetal kidney (H \&E 10X). (A) Control, (B) DMSO, (C) quercetin (75 mg/kg), (D) quercetin $(200 \mathrm{mg} / \mathrm{kg})$. Orange arrow: periglomerular space, blue arrow: distal tubule, green arrow: proximal tubule, bilateral arrow: diameter of corpuscles

\section{RESULTS}

Percentages of absorbed fetuses were 66.66, 47.05 and 45.71 in groups 2,6 and 7, respectively, so quercetin decreased the resorption rate. No maternal deaths were observed throughout the course of this study.

Kidneys were bilaterally present and normal in shape in all fetuses of the total groups. On histological examination, the sagittal section of kidneys from the control group showed well developed cortical renal corpuscles. In control, DMSO and quercetin alone groups, kidney showed no pathological appearances (Fig. 2).

On histological evaluation of kidney from treated group of fetuses, it was observed that there was severe degeneration of glomeruli. There was increased periglomerular space in sections of treated groups of kidney (Table I).
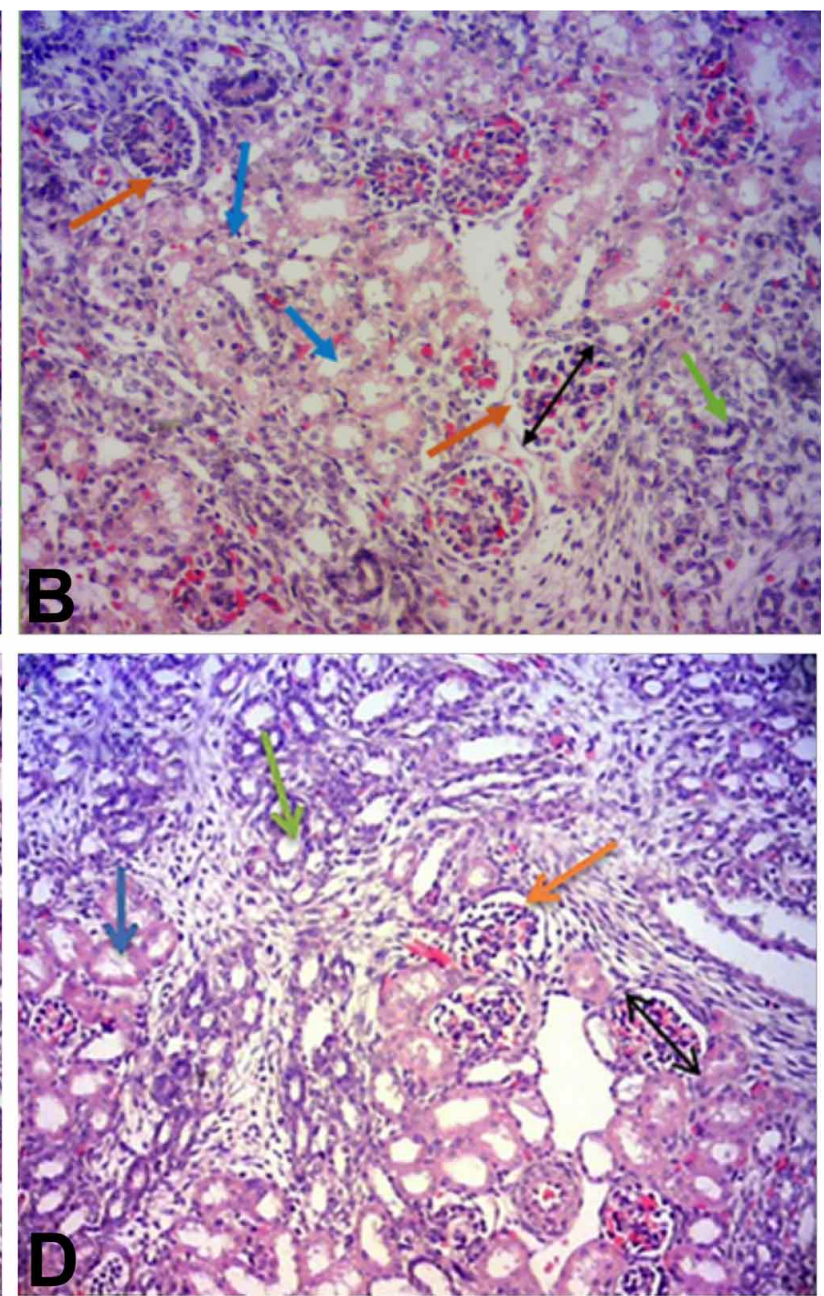
The mean of number of renal corpuscles of animals' fetuses that received atRA in 8-10th days was significantly decreased in comparison with normal saline group. The mean of diameter of renal corpuscles of animals' fetuses that received atRA significantly increased in comparison with other groups except with atRA plus quercetin $(75 \mathrm{mg} / \mathrm{kg})$. The mean of diameter of periglomerular space of animals' fetuses that received atRA significantly increased in comparison with other groups (Fig. 3) (Table I).
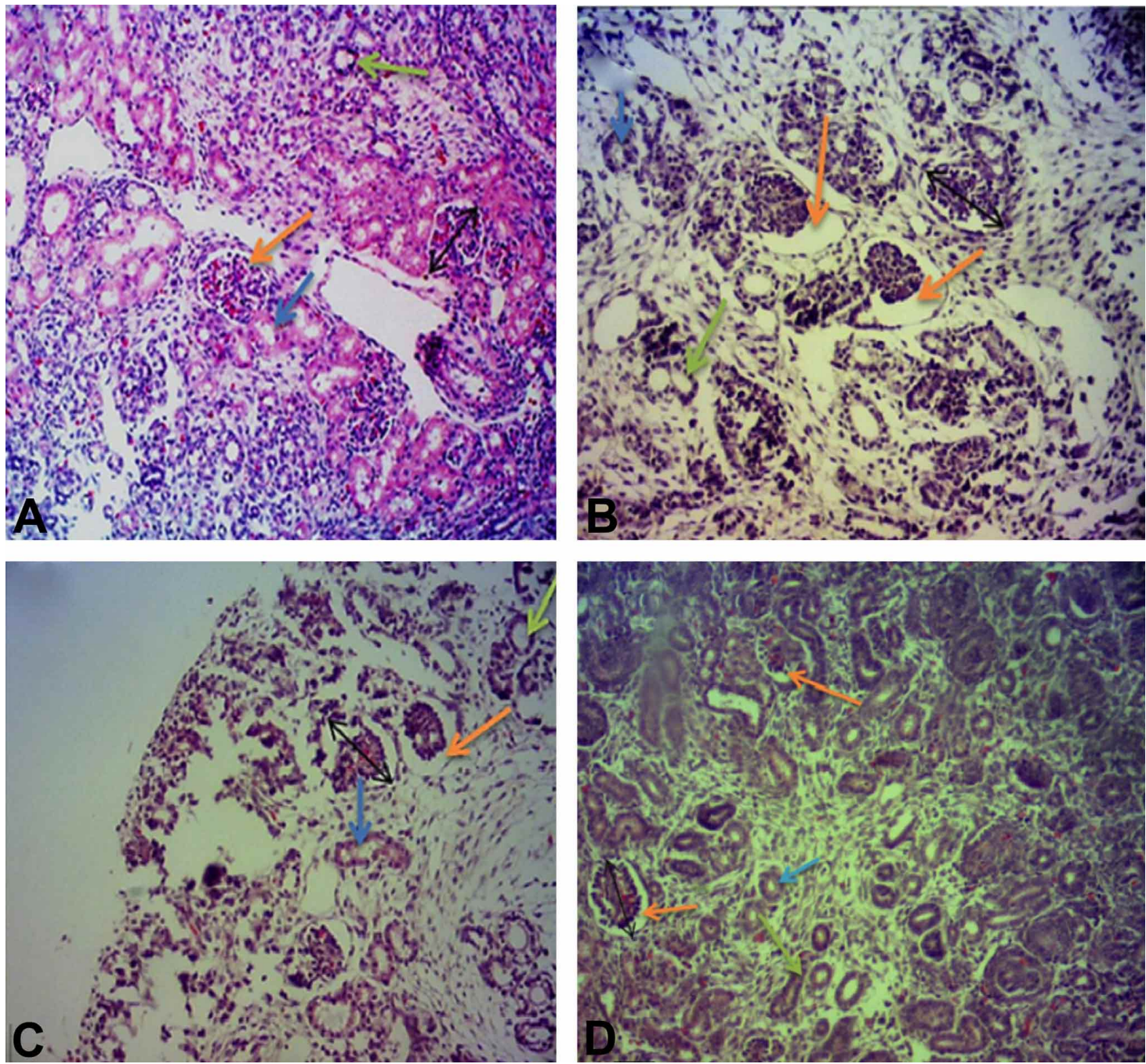

Fig. 3. Histological structure of sagittal section of fetal kidney (H \&E 10X). (A) Control, (B) atRA , (C) atRA plus quercetin $(75 \mathrm{mg} / \mathrm{kg})$, (D) atRA plus quercetin $(200 \mathrm{mg} / \mathrm{kg})$. Orange arrow: periglomerular space, blue arrow: distal tubule, green arrow: proximal tubule, bilateral arrow: diameter of corpuscles.

Table I. Morphometric analysis of renal glomeruli in control and experimental animals. Group1 (control); Group 2 received atRA; Group 3 received DMSO; Group 4 received quercetin ( $75 \mathrm{mg} / \mathrm{kg})$, Group 5 received quercetin (200 mg/kg); Group 6 received atRA plus quercetin $(75 \mathrm{mg} / \mathrm{kg})$; Group7 received atRA plus quercetin $(200 \mathrm{mg} / \mathrm{kg})$.

\begin{tabular}{lccc}
\hline Groups & Mean number of corpuscles & Mean Diameter of corpuscles & Mean diameter of periglomerural \\
\hline Group1 & $13.666 \pm 0.186 \mathrm{ac}$ & $65.516 \pm 0.975 \mathrm{a}$ & $4.624 \pm 0.145 \mathrm{a}$ \\
Group2 & $10.384 \pm 0.407 \mathrm{~b}$ & $74.843 \pm 1.352 \mathrm{~b}$ & $15.926 \pm 0.519 \mathrm{~b}$ \\
Group3 & $12.928 \pm 0.126 \mathrm{acd}$ & $68.884 \pm 1.232 \mathrm{a}$ & $5.886 \pm 0.209 \mathrm{c}$ \\
Group4 & $12.384 \pm 0.212 \mathrm{~cd}$ & $67.014 \pm 1.131 \mathrm{a}$ & $4.303 \pm 0.141 \mathrm{a}$ \\
Group5 & $12.933 \pm 0.118 \mathrm{acd}$ & $68.428 \pm 0.759 \mathrm{a}$ & $4.539 \pm 0.134 \mathrm{a}$ \\
Group6 & $10.833 \pm 0.321 \mathrm{~b}$ & $74.402 \pm 1.035 \mathrm{~b}$ & $11.165 \pm 0.764 \mathrm{~d}$ \\
Group7 & $11.076 \pm 0.264 \mathrm{~b}$ & $69.452 \pm 1.439 \mathrm{a}$ & $6.672 \pm 0.354 \mathrm{c}$ \\
\hline
\end{tabular}

*-Different letters indicate significant differences within the column $(\mathrm{P}<0.0001)$ 


\section{DISCUSSION}

In the present study for first time, the effect of quercetin on histomorphometrically changes in kidney of rat fetuses treated by atRA was evaluated. We demonstrated astRA (at dose $25 \mathrm{mg} / \mathrm{kg}$, IP) decreased number of renal corpuscles and increased periglomerular space and diameter of renal corpuscles.

Elmazar et al. (1996) found hypoplasia of kidney, hydronephrosis and hydroureter after administration of RA ( $37.5 \mathrm{mg} / \mathrm{kg}$ body weight). In the present study we focused on the effects of RA on histological structure of fetal kidney. The RA was given on 8-10th of gestation, considered to be critical for developing kidney, since nephrogenic cords are reported to appear by 8th day and pronephric tubules and duct are observed to be suspended in the coelom by 10 th day (Naseer \& Tahir, 2012).

Examination of the sagittal section of kidneys from control group showed normal looking well developed organ with outer cortex and inner medulla, whereas those from experimental group, showed increase in periglomerular space and diameter of renal corpuscles induced by RA. Similar findings were reported earlier in which development of the collecting duct system was greatly impaired in RAR ab2mutant mice embryo; fewer branches of ureteric bud were present, and their ends were positioned abnormally at a distance from the renal capsule (Mendelsohn et al., 1999).

The results presented here show that quercetin administration during the gestational period has a partial protective effect on atRA-induced teratogenesis (decreasing periglomerural space, increasing number of renal corpuscles). It is well established that atRA is an important physiological regulator of embryonic development; it regulates many processes in organogenesis such as development of important organs and systems including the heart, the cardiovascular system, the hindbrain, and the foregut, among others (Ali-Khan \& Hales, 2006). However, both its deficiency and excess can result in abnormal embryonic development. When atRA is administered in large doses during this critical period GD 8-10, it causes embryonic malformations in a dosedependent manner. Inappropriate gene expression has been proposed as a mechanistic basis for atRA teratogenicity. Morphological changes visible after atRA treatment of embryos could be explained by alterations in the spatial and temporal patterns of expression of genes controlling differentiation, proliferation, apoptosis, and morphogenesis in embryonic organization and in initial axial patterning (Mulder et al., 2000).
Interestingly, inactivation of both RARa and RARb in mice fetuses resulted in renal malformations (Mendelsohn et al., 1994). Further evidence showed that RARa and RARb were coexpressed with Ret, a receptor tyrosine kinase involved in renal development, in renal stromal mesenchyme, where their deletion led to altered stromal cell patterning, impaired ureteric bud growth, and down-regulation of Ret in the ureteric bud. Moreover, studies in mice indicate that the RA signaling in ureteric bud cells mainly depends on atRA generated through Raldh2 in stromal cells (Malpel et al., 2000).

The kidney is an organ highly vulnerable to damage caused by reactive oxygen species (ROS), likely due to the abundance of polyunsaturated fatty acids in the composition of renal lipids. ROS are involved in the pathogenic mechanism of conditions such as glomerulosclerosis and tubulointerstitial fibrosis.

AtRA plays important role in the control of cell differentiation and morphogenesis during prenatal development. However atRA, used in the treatment of dermatological disorders, has been implicated in the production of congenital anomalies in infants born to mothers taking the drugs during the first trimester. The critical period for atRA exposure appears to be 2-5 weeks postconception for humans (Holson et al., 1997).

Also, we observed protective effect of quercetin on atRA teratogenicity. This effect reported by some researchers. For example; Prater et al. (2008) reported that low-dose quercetin $(66 \mathrm{mg} / \mathrm{kg}$ supplemented in rodent chow throughout gestation; approximately $70 \%$ of human dose), high-dose quercetin $(333 \mathrm{mg} / \mathrm{kg}$ supplemented in rodent chow throughout gestation; approximately $3.5 \mathrm{x}$ daily human dose), impairs placental oxidative stress and fetal skeletal malformation induced by methylnitrosourea.

In one study, quercetin treatment prevents renal tubular damage and increased oxidative stress induced by chronic cadmium administration, most probably throughout its antioxidant properties (Morales et al., 2006).

Devi \& Shyamala (1999) reported quercetin (20 mg/ $\mathrm{kg}$, i.p., once a week x5) has significant cytoprotective effect in cisplatin-induced renal tubular damage in vivo in rats. In one study, quercetin could protect the rat kidney against leadinduced injury by improving renal function, attenuating histopathologic changes, reducing ROS production, renewing the activities of antioxidant enzymes, decreasing DNA oxidative damage and apoptosis (Liu et al., 2010).

Gupta et al. (2010) reported that quercetin (10, 30 and $100 \mathrm{mg} / \mathrm{kg}$ ) for 5 consecutive days) ameliorates the 
diethylnitrosamine induced hepatotoxicity in rats and can be a candidate for a good chemoprotectant.

Also, quercetin reduced abnormal development of mouse embryos produced by hydroxyurea. Liang et al. (2009) demonstrated that quercetin $(66 \mathrm{mg} / \mathrm{kg}$ supplemented diet) significantly improves high fatty saturated induced fetal skeletal maldevelopment, perhaps in part due to antioxidant effects of quercetin in placenta. This speculation is supported by previous reports that demonstrate quercetin prevention of oxidant injury and cell death by ROS scavenging and protection against lipid peroxidation

In another study, quercetin with dose $50 \mathrm{mg} / \mathrm{kg}$ orally was most effective in preventing arsenic poisoning by reducing oxidative stress (Dwivedi \& Flora, 2011).

In conclusion, the present study showed the effects of quercetin for the first time on histomorphometrically changes induced atRA in kidney of rat fetuses. The present results indicate that exposure $25 \mathrm{mg} / \mathrm{kg}$ of atRA in 8-10th days of gestation of rat decreases number of renal corpuscles and increase diameter of renal corpuscles and periglomerural space in kidney of fetuses. The protective effect of quercetin in atRA -induced histomorphometrical changes in kidney of rat fetuses may, at least in part, be due to its antioxidant activity, which we believe deserves further investigation.

\section{ACKNOWLEDGEMENTS}

Hereby, research deputy of Shahid Chamran University of Ahvaz will be highly appreciated for financial funding of this study.

KHAKSARY-MAHABADY, M.; RANJBAR, R.; NAJAFZADEH-VARZI, H.; MOHAMMADIAN, B. \& GOHARI-BEHBAHANI, N. Efecto protector de la quercetina sobre los cambios histomorfométricos en el riñón de fetos de rata tratados con ácido retinoico. Int. J. Morphol., 36(1):338-344, 2018.

RESUMEN: El ácido retinoico, un metabolito activo de la vitamina A, desempeña un papel esencial de señalización en la embriogénesis de mamíferos. La exposición al ácido retinoico en fetos de ratas prenatales induce malformaciones en varios órganos, siendo el metabolito más activo y teratogénico el ácido transretinoico (ATRA). Los efectos teratogénicos de algunos medicamentos se pueden prevenir mediante la aplicación de medicamentos antioxidantes y la estimulación del sistema inmune materno. Además, la quercetina, un flavonoide de origen natural, tiene excelentes propiedades antioxidantes. Por lo tanto, el objetivo de este estudio fue evaluar los efectos protectores de quercetina contra
ATRA en fetos de tejido de riñón de rata. Este estudio se realizó en 40 ratas preñadas que se dividieron en siete grupos. El grupo control recibió solución salina normal y los grupos de prueba recibieron DMSO, quercetina ( $75 \mathrm{mg} / \mathrm{kg}$ ), quercetina (200 mg / kg), ATRA (25 mg / kg), ATRA (25 mg / kg) más quercetina (75 mg / $\mathrm{kg}$ ) y ATRA (25 mg / kg) más quercetina (200 mg / kg), por vía intraperitoneal a los 8-10 días de gestación. Los fetos se recolectaron a los 20 días de gestación. Los riñones se recogieron y se colocaron en solución de formalina tamponada al $10 \%$. Luego, los riñones se seccionaron por método de rutina y se tiñeron con $\mathrm{H}$ \& E y se examinaron histológicamente. En el examen histomorfométrico, se observó que el espacio periglomerular y el diámetro del corpúsculo renal en el grupo que recibió solo ATRA fueron significativamente $(\mathrm{p} \leq 0.05)$ mayores que los que recibieron solución salina normal, dimetilsulfóxido y quercetina, mientras que estos dos índices, en el grupo que recibió ATRA más quercetina, disminuyó significativamente $(\mathrm{p} \leq 0.05)$ en forma dependiente de la dosis. El número de corpúsculos renales disminuyó significativamente $(\mathrm{p} \leq 0.05)$ por el ATRA, pero la quercetina no pudo afectar el número de glomérulos. Se concluye que la quercetina puede proteger a los fetos contra daños de ATRA y prevenir su incidencia, probablemente, a través de su efecto antioxidante.

PALABRAS CLAVE: Ácido retinoico; Quercetina; Histomorfometría; Feto; Rata.

\section{REFERENCES}

Abu-Abed, S.; MacLean, G.; Fraulob, V.; Chambon, P.; Petkovich, M. \& Dollé, P. Differential expression of the retinoic acid-metabolizing enzymes CYP26A1 and CYP26B1 during murine organogenesis. Mech. Dev., 110(1-2):173-7, 2002.

Ali-Khan, S. E. \& Hales, B. F. Novel retinoid targets in the mouse limb during organogenesis. Toxicol. Sci., 94(1):139-52, 2006.

Bhat, P. V. \& Manolescu, D. C. Role of vitamin A in determining nephron mass and possible relationship to hypertension. J. Nutr., 138(8):140710, 2006.

Devi, P. S. \& Shyamala, D. C. S. Protective effect of quercetin in cisplatininduced cell injury in the rat kidney. Indian J. Pharmacol., 31(6):4226, 1999.

Duester, G. Retinoic acid synthesis and signaling during early organogenesis. Cell, 134(6):921-31, 2008.

Dwivedi, N. \& Flora, S. J. S. Dose dependent efficacy of Quercetin in preventing arsenic induced oxidative stress in rat blood and liver. $J$. Cell Tissue Res., 11(1):2605-11, 2011.

Elmazar, M. M. A.; Reichert, U.; Shroot, B. \& Nau, H. Pattern of retinoidinduced teratogenic effects: Possible relationship with relative selectivity for nuclear retinoid receptors RARa, RARb, and RARg. Teratology, 53(3):158-67, 1996.

Goldberg, D. M.; Hahn, S. E. \& Parkes, J. G. Beyond alcohol: beverage consumption and cardiovascular mortality. Clin. Chim. Acta, 237(12):155-87, 1995.

Gupta, C.; Vikram, A.; Tripathi, D. N.; Ramarao, P. \& Jena, G. B. Antioxidant and antimutagenic effect of quercetin against DEN induced hepatotoxicity in rat. Phytother. Res., 24(1):119-28, 2010.

Holson, R. R.; Gazzara, R. A.; Ferguson, S. A. \& Adams, J. A behavioral and neuroanatomical investigation of the lethality caused by gestational day 11-13 retinoic acid exposure. Neurotoxicol. Teratol., 19(5):347-53, 1997. 
Kam, R. K. T.; Deng, Y.; Chen, Y. \& Zhao, H. Retinoic acid synthesis and functions in early embryonic development. Cell Biosci., 2:11, 2012.

Liang, C.; Oest, M. E.; Jones, J. C. \& Prater, M. R. Gestational high saturated fat diet alters C57BL/6 mouse perinatal skeletal formation. Birth Defects Res. B Dev. Reprod. Toxicol., 86(5):362-9, 2009.

Liu, C. M.; Ma, J. Q. \& Sun, Y. Z. Quercetin protects the rat kidney against oxidative stress-mediated DNA damage and apoptosis induced by lead. Environ. Toxicol. Pharmacol., 30(3):264-71, 2010.

Maciel, R. M.; Costa, M. M.; Martins, D. B.; França, R. T.; Schmatz, R.; Graça.; D. L.; Duarte, M. M.; Danesi, C. C.; Mazzanti, C. M.; Schetinger, M. R.; Paim, F. C.; Palma, H. E.; Abdala, F. H.; Stefanello, N.; Zimpel, C. K.; Felin, D. V. \& Lopes, S. T. Antioxidant and antiinflammatory effects of quercetin in functional and morphological alterations in streptozotocin-induced diabetic rats. Res. Vet. Sci., 95(2):389-97, 2013.

Maden, M. Retinoids and spinal cord development. J. Neurobiol., 66(7):72638, 2006.

Malpel, S.; Mendelsohn, C. \& Cardoso, W. V: Regulation of retinoic acid signaling during lung morphogenesis. Development, 127(14):3057-67, 2000.

Mark, M.; Ghyselinck, N. D. \& Chambon, P. Function of retinoid nuclear receptors: lessons from genetic and pharmacological dissections of the retinoic acid signaling pathway during mouse embryogenesis. Аnпи. Rev. Pharmacol. Toxicol., 46:451-80, 2006.

Mendelsohn, C.; Batourina, E.; Fung, S.; Gilbert, T. \& Dodd, J. Stromal cells mediate retinoid-dependent functions essential for renal development. Development, 126(6):1139-48, 1999.

Mendelsohn, C.; Lohnes, D.; Décimo, D.; Lufkin, T.; LeMeur, M.; Chambon, P. \& Mark, M. Function of the retinoic acid receptors (RARs) during development (II). Multiple abnormalities at various stages of organogenesis in RAR double mutants. Development, 120(10):274971, 1994.

Morales, A. I.; Vicente-Sánchez, C.; Sandoval, J. M.; Egido, J.; Mayoral, P.; Arévalo, M. A.; Fernández-Tagarro, M.; López-Novoa, J. M. \& Pérez-Barriocanal, F. Protective effect of quercetin on experimental chronic cadmium nephrotoxicity in rats is based on its antioxidant properties. Food Chem. Toxicol., 44(12):2092-100, 2006.

Mulder, G. B.; Manley, N.; Grant, S.; Schmidt, K.; Zeng, W.; Eckhoff, C. \& Maggio-Price, L. Effects of excess vitamin A on development of cranial neural crest-derived structures: a neonatal and embryologic study. Teratology, 62(4):214-26, 2000.

Naseer, U. \& Tahir, M. Effects of vitamin A on fetal kidneys in albino mice: A histological study. Pak. J. Zool., vol. 44(4):1045-50, 2012.

Notario, B.; Zamora, M.; Viñas, O. \& Mampel, T. All-trans-retinoic acid binds to and inhibits adenine nucleotide translocase and induces mitochondrial permeability transition. Mol. Pharmacol., 63(1):224-31, 2003.

Perez-Vizcaino, F.; Duarte, J.; Jimenez, R.; Santos-Buelga, C. \& Osuna, A. Antihypertensive effects of the flavonoid quercetin. Pharmacol. Rep., 61(1):67-75, 2009.

Prater, M. R.; Laudermilch, C. L.; Liang, C. \& Holladay, S. D. Placental oxidative stress alters expression of murine osteogenic genes and impairs fetal skeletal formation. Placenta, 29(9):802-8, 2008.

Vilar, J.; Gilbert, T.; Moreau, E. \& Merlet-Bénichou, C. Metanephros organogenesis is highly stimulated by vitamin A derivatives in organ culture. Kidney Int., 49(5):1478-87, 1996.

Wagner, J. Potential role of retinoids in the therapy of renal disease. Nephrol. Dial. Transplant., 16(3):441-4, 2001.

\author{
Corresponding author: \\ Mahmood Khaksary-Mahabady \\ Associate Professor \\ Department of Anatomy and Embryology \\ Faculty of Veterinary Medicine \\ Shahid Chamran University of Ahvaz \\ Ahvaz \\ IRAN
}

Email: mkhaksary@scu.ac.ir

Received: $30-06-2017$

Accepted: 30-10-2017 